\title{
FINANCIAL DISTRESS ANALYSIS USING THE ZMIJEWSKI METHOD
}

\author{
Edon Ramdani \\ Universitas Pamulang, Tangerang Selatan, Indonesia \\ Email: edon ramdani@yahoo.com
}

\begin{abstract}
This study aimed to determine the level of financial distress of the company using the Zmijewski method and conducted on three companies listed on the Indonesia Stock Exchange, namely PT Bakrieland Development Tbk, PT Central Omega Resources Tbk and PT Buana Lintas Lautan Tbk who received warnings from the IDX due to the delay in submitting financial reports. The results: the three companies are in good condition, with no financial distress. PT Bakrieland Development Tbk and PT Buana Lintas Lautan Tbk showed an increase in performance during the year 2016-2018 but PT Central Omega Resources Tbk decreased during the year 2016-2018. Companies are required to maintain the ability to meet their obligations and reduce the level of obligation so that it can be maintained does not lead to financial distress. Delays in the delivery of financial statements must be reduced so as not to harm investors. Analysis of financial distress needs to be continued to determine the company's financial condition. Contrast to previous studies that analyzed financial distress by comparing testing models and testing on companies listed on the IDX, this study focused on testing companies that received IDX warnings due to late financial reporting.
\end{abstract}

Keywords: financial distress, IDX, financial statements, Zmijewski Method

ARTICLE INFORMATIONS

Article history: submitted: May, 15 2020; revised: June, 1 2020; accepted: June, 162020

JEL Classifiction: G01

How to cited: Ramdani, E. (2020). Financial Distress Analysis Using The Zmijewski Method. JIMFE (Jurnal

IImiah Manajemen Fakultas Ekonomi), 6(1), 69-78. https://doi.org/10.34203/jimfe.v6i1.2032

Copyright@2020. JIMFE (Jurnal IImiah Manajemen Fakultas Ekonomi) Universitas Pakuan

\section{INTRODUCTION}

Every company established aims to generate profits and can continue in the future. This assumption is sometimes not as expected. It often happens that companies that have been operating for a long time are forced to stop operating or are liquidated due to financial difficulties which then lead to bankruptcy.

The company's activities in generating profits, can be through the production of goods and/or services and then marketed and sold for profit, also can buy merchandise or services and then resell at price differences as expected profit. To maintain a stable income, the company must maintain the level of sales of products and services it produces. Every company will experience a phase where sales levels sometimes grow up, sometimes down. Companies that have increased sales are certainly expected to get increased profits and conversely, companies that have decreased sales tend to suffer losses. A decrease in sales can result in a decrease in the company's financial performance. It is very crucial how the company can continue to maintain its profit. With profit, the company is expected to be able to maintain its growth, continue to exist (going concern), develop in the long term, and not liquidated due to wrong financial management. The company's financial performance can be used as a measure of the company's success in generating profits, so the company can see its growth potential. Financial performance is also useful for investors in determining investments and from the company's financial performance reports investors will be considered before deciding to invest. 
Investment in a company often runs the risk of uncertainty in the future. These risks can occur where there is no return on investment as expected because the company is experiencing financial distress due to losses suffered. This sometimes happens because the company is unable to fulfill its payment obligations. Many companies are forced to be liquidated or disbanded because they continue to experience financial difficulties that end in bankruptcy.

Analysis needs to be done to find out the symptoms of a decline in financial performance, so it can be anticipated the occurrence of bankruptcy in the future. Analysis of financial difficulties can be done by analyzing the data in the company's annual financial statements. Company financial statements are tools that can be used to evaluate company performance. Evaluation of company performance can be done using a financial ratio analysis approach.

This research was conducted in PT Bakrieland Development Tbk (ELTY), PT Buana Lintas Lautan Tbk (BULL), and PT Central Omega Resources Tbk (DKFT) that listed in the Indonesia Stock Exchange and is engaged in various fields. The three companies received warnings and fines for delays in the submission of financial statements that ended as of June 30,2019 . In addition to the three companies, there were at least 16 companies that received warnings and fines. Submission of financial statements by companies listed on the IDX is an obligation. Delay in financial reporting can result in a decline in the performance of the stock exchange, as well as affect the perspective of investors to spend/invest their capital in the shares of these companies.

The delay in financial reporting can be caused by several factors, including the company's performance that is not good. To find out whether the company is in decline in performance or experiencing financial difficulties that lead to bankruptcy can be analyzed using various models of financial statement analysis approaches. This study was conducted specifically to test whether companies that experience delays in financial reporting to the Indonesia Stock Exchange are caused by a decline in financial performance so that companies need time to prepare their financial statements carefully so that the financial statements provided do not harm the market. In contrast to previous studies that only tested companies listed on the Indonesia Stock Exchange, it was not specific to companies that experienced warnings from the Indonesia Stock Exchange. As research conducted by Kusumaningtyas (2017) analysis of bankruptcy predictions using the Zmijewski, Springate and Fulmer models of retail companies on the Indonesian stock exchange revealed, The results showed that based on the model of Zmijewski, there were 13 companies $(15.29 \%)$ of the total companies in the study period experienced unsanitary conditions, and there are five companies (29.41\%) of the 17 companies each year has an unhealthy condition. Based on the model Springate there are 18 companies $(22.35 \%)$ of the total companies in the study period experienced unsanitary conditions, and there are 7 companies $(41.18 \%)$ of the 17 companies experienced an unhealthy condition. And based on the model Fulmer there are 7 companies $(8.24 \%)$ of the total companies in the study period experienced unsanitary conditions, and there are three companies (17.65\%) of the 17 companies experienced unsanitary conditions. Overall, the model Springate is a model that gives better prediction than most other models. Then research conducted by Randy Kurnia Permana, Nurmala Ahmar, Syahril Djadang (2017) Prediction of Financial Distress in Manufacturing Companies in the Indonesian stock exchange revealed, the result showed that there are differences in health status in the test model of Grover, Springate and Zmijewski on manufacturing companies listed on the stock exchange 2006-2015. Model Springate is the predictive model than the Grover and Springate because it has more components 
than the others and the Springate model have EBIT to Current Liabilities.

\section{LITERATURE REVIEW Financial Distress}

Financial difficulties often also referred to as financial distress can occur before the company went bankrupt. Financial difficulties are the initial indicator before the company goes bankrupt or is liquidated due to the deterioration of financial conditions. According to Beaver (2011), financial difficulties can also be interpreted as the company's inability to pay its financial obligations that are past due

Financial difficulties can occur in various companies and is a marker / an early signal of bankruptcy that may be experienced by the company. If the company enters financial distress, management must be careful because it might enter the bankruptcy stage. Management of companies experiencing financial distress is required to take action to overcome the problem and prevent bankruptcy.

Financial distress is a condition where the company's finances are in an unhealthy state or experiencing a crisis. Financial distress will interfere with the company's operational activities and it is important to be immediately watched and anticipated. Financial difficulties can occur due to several factors, including; bad corporate governance, the limited ability of leaders, managers, and subordinates to run the company, skills, and expertise that are not suitable for managing company finances.

According to Rodoni and Ali (2010) when viewed from the financial condition three conditions cause financial distress, namely the factor of capital insufficiency or lack of capital, the amount of debt and interest burden, and suffering losses. The three aspects are interrelated and it must be maintained in balance so that the company avoids the conditions of financial difficulties that lead to bankruptcy.
Many factors cause financial distress. According to Lizal (2002), classifying causes of difficulties, called the basic model of bankruptcy or the trinity of causes of financial difficulties, There are three main reasons why companies experience financial distress and then go bankrupt, as follows: First, Neoclassical Financial distress and bankruptcy models occur if the allocation of resources within the company is not right. Management is less able to allocate resources (assets) in the company to the company's operational activities. Second, the financial model of mixing assets is right but the financial structure is wrong with liquidity constraints. This means that although the company can survive in the long run, it must also go bankrupt in the short term. Third, the corporate governance model according to this model, bankruptcy has the right mix of assets and financial structures but is poorly managed. This inefficiency drives companies to become out of the market as a consequence of unresolved problems in corporate governance.

In the financial crisis in Asia that occurred in 1997-1998, a lot of literature shows that corporate governance is one of the factors causing financial difficulties. Corporate governance can cause companies to experience financial difficulties when ownership is concentrated (ownership concentration) and poor management (poor corporate governance). Poor governance of companies becomes a way/opportunity for controlling shareholders (majority) to transfer the value of the company into their own pockets, as stated by Hsin (2008). Reducing the value of the company will make the company towards greater financial distress (Dwijayanti, 2010).

Macroeconomic conditions can also cause financial difficulties in addition to problems of corporate governance, financial distress. According to Liou and Smith (2007) suggested that macroeconomic factors have a significant impact on the occurrence of financial difficulties and can also have an 
impact on company bankruptcy. Some of the macroeconomic factors include inflation, interest rates, Gross National Products, availability of credit, employee wage rates, and also tight monetary policy.

According to Endang (2013), the condition of financial distress will have an impact on the decline in firm value, a decrease in the quality of relationships with customers, with employees and with creditors and demotivation of employees, thereby reducing job security. Pranowo (2010), states that companies that have Debt Service Coverage Ratio (DSCR) < 1.2 as distress companies. Ardiyanto and Prasetiono (2011), used negative earnings per share (EPS) for several years to determine the condition of company distress according to the research of Elloumi and Gueyie (2001).

Then based on Dun and Bradstreet's research that business failure is caused by several factors including Economic factors which include weak industry and non-strategic location, financial factors, including too much debt and weak/insufficient capital. Managerial weakness, fraud, and disaster factors.

Table 1. Causes of Business Failure

\begin{tabular}{l|r}
\hline \multicolumn{1}{c|}{ Factor } & \multicolumn{1}{c}{ Percentage } \\
\hline Economic Factor & $37.1 \%$ \\
\hline Financial Factor & $47.3 \%$ \\
\hline $\begin{array}{l}\text { Governance, Fraud, } \\
\text { and Natural Disasters }\end{array}$ & $14.0 \%$ \\
\hline Others factor & $1.6 \%$ \\
\hline Total & $100.0 \%$ \\
\hline
\end{tabular}

Source: Dun \& Bradstreet Inc., Business Failure Record (2011)

It should be underlined that the factors in table 1 vary from time to time, depending on economic conditions and interest rates. Most business failures are caused by a combination of those factors, which causes the business to become unsustainable. Furthermore, studies show that financial difficulties are usually the result of a series of mistakes, misjudgments, and interrelated weaknesses that can be directly or indirectly linked to management.

Signs of potential financial difficulties can generally be seen with financial ratio analysis. Long before the company failed, researchers used ratio analysis to predict the likelihood of a particular company going bankrupt. Conditions of financial difficulties must be anticipated, so it is necessary to develop financial distress prediction models so that actions can be taken to anticipate bankruptcy. The parties who need this prediction model according to Ray (2011):

Company managers: predictive models can motivate managers to identify problems and take effective action to reduce the possibility of distress.

Auditor: this model can give early warning to negligent auditors and protect them against claims for negligence because it does not expose the possibility of corporate financial difficulties.

Lender: this model can be used to assess a company's failure on its loans.

Regulatory body: this agency will monitor the company for the danger of financial difficulties. Several methods can be done including analyzing the company's performance using financial ratios.

\section{Measurement Model of Financial Distress}

Financial distress should be anticipated early as a way to prevent bankruptcy, so we need a tool or model to determine the symptoms of financial distress. This anticipatory model/tool is expected to help stakeholders take the necessary policies. Even with this model can help investors and creditors in making investment decisions or lending so as not to get caught up in these conditions of financial distress. Several models have been developed including:

\section{Springate Model}

This method is a development of the Altman method using multiple discriminant analysis (MDA) (Springate, 1978). Initially, this method 
used 19 popular financial ratios, but after retesting Springate finally chose 4 ratios used in determining the criteria for companies included in the category of healthy and potentially bankrupt companies.

The following is the formulation of the Springate model:

$S=1,03 A+3,07 B+0,66 C+0,4 D$

Where:

$A=$ Working capital $/$ Total asset

$B=$ Net profit before interest and taxes / Total asset

$\mathrm{C}=$ Net Profit before taxes / Current liabilities

$D=$ Sales $/$ Total asset

With a cut off if the value of Springate is greater than 0.862 , the company is categorized as healthy while if the value of Springate is less than 0.862 , the company is categorized as unhealthy and potentially bankrupt.

\section{Grover Model}

The Grover model was developed by Jeffrey $\mathrm{S}$ Grover in 1968. The Grover model was created by designing and re-evaluating the Altman ZScore model.

The formulation of the Grover model:

$S=1,650 \times 1+3,404 \times 3+0,016$ ROA +0.057

Where:

X1= Working capital / Total asset

X3= Earning before interest and taxes / Total asset

ROA $=$ Net income $/$ Total asset

With a cut off if the score is less or equal to $-0.02(Z \leq-0.02)$, the company is indicated to be unhealthy, while the company is categorized as healthy if the score is equal or more than $0.01(z \geq 0.01)$.

\section{Zmijewski Model}

The next model is the Zmijewski Model prediction model produced by Zmijewski (1984). Zmijewski uses the financial ratio of return on assets (ROA), leverage, and liquidity to get a more appropriate pattern (Zmijewski, 1984). This financial ratio was chosen not based on theory but derived from previous experience and research (Zmijewski, 1984).

The formulation of the Zmijewski model is as follows:

$X=-4,3-4,5 \times 1+5,7 \times 2-0,004 \times 3$

Where :

$\mathrm{X} 1=\mathrm{ROA}$ (Return on Asset)

X2 = Laverage (Debt Ratio)

X3 = Likuiditas (Current Ratio)

With a cut off if the resulting score exceeds 0 then the company is predicted to experience financial difficulties and vice versa if the score is less than 0 then the company is categorized as not having the potential to experience financial difficulties/bankruptcy.

\section{METHOD}

This research uses a quantitative descriptive method by collecting data obtained from the company's financial statements published on the Jakarta Stock Exchange, then the data is classified based on the variables needed in the research method used, then the results of the data processing are analyzed and interpreted to produce conclusions about the actual situation.

Sugiyono (2013) in his research suggested a descriptive method is a method that can explain the formulation of problems relating to the question of the independent variable, either for one or several variables. The data used in this study are secondary in the form of documentation and literature study. And the data was obtained indirectly from the research company (subject) but the Indonesia Stock Exchange website and the company website.

The data analysis model used in this study is the Zmijewski Method. As for the use of the Zmijewski method in this study because, this method has combined several financial ratios, providing a coefficient that matches the combination of independent variables that exist and the Zmijewski method is easy to apply and widely used. 
Edon Ramdani: Financial Distress Analysis ...

RESULTS AND DISCUSSION

The following is a table of net income for the period of 2016-2018:

Table 2. Nett Income 2016-2018 (IDR Million)

\begin{tabular}{llll}
\hline Company & $\mathbf{2 0 1 6}$ & $\mathbf{2 0 1 7}$ & $\mathbf{2 0 1 8}$ \\
\hline PT Bakrieland Development Tbk & -547.265 & -266.476 & 2.726 .725 \\
\hline PT Central Omega Resources Tbk & -87.161 & -44.594 & -93.547 \\
\hline PT Buana Lintas Lautan Tbk (in US \$) & 485.433 & 11.204 .709 & 14.860 .237 \\
\hline
\end{tabular}

Source: Indonesian Stock Exchange, 2020

From the table above it can be seen that PT Bakrieland Development Tbk suffered losses throughout 2016-2017 and gained positive growth in 2018, then for PT Central Omega Resources Tbk experienced a minus throughout 2016-2018, while PT Buana Lintas Lautan Tbk experienced a profit increase in 2016-2018, but it will still be simulated whether the company experiences financial distress or not.

\section{Analysis Method}

To find out whether companies experiencing financial distress that leads to bankruptcy can use various methods of financial statement analysis. One method of analysis that can be used is the Zmijewski method. This method how to calculate it is quite easy and quite accurate, the financial distress analysis can be used by the company for assessment and also a consideration of the company's condition in the future.

Zmijewski's method by Mark Zmijewski in 1984 and called Zmijewski is a formula obtained from several pre-existing methods that have been developed by him. According to Peter and Yoseph (2011), Zmijewski adds the validity of financial ratios as a means of detecting corporate financial failures. Zmijewski conducted a study by reviewing the field of bankruptcy studies from the results of previous research for twenty years.

The data analysis technique used in this study is the Zmijewski Method. According to Kusumaningtyas (2017), Zmijewski in his research requires one crucial thing. The proportion of the sample and population must be determined at the earliest so that the frequency of financial distress is obtained. This frequency is obtained by dividing the number of samples that experience Financial Distress by the total sample size (Rismawaty, 2012). The Zmijewski method was first used in research on 40 bankrupt companies and 800 non-bankrupt companies.

Here is the formula put forward by Zmijewski: $X$-Score $=-4.3-4,5 X 1+5.7 \times 2-0.004 X 3$ (4) Where :

X1 = EAT / Total Assets (Return On Assets)

X2 = Total Debt / Total Assets (Debt Ratio / Leverange)

$\mathrm{X} 3$ = Current Assets / Current Liabilities (Current Ratio or Liquidity)

The cut-off used in this method is 0 , where if the X-Score results are positive, the company is said to be unhealthy. Whereas if the $\mathrm{X}$-Score results are negative, the company is said to be healthy. The accuracy rate of the Zmijewski method is $94.9 \%$. (Purnajaya and Merkusiwati, 2014).

Based on data released by PT Bakriland Development Tbk, PT Central Omega Resources Tbk, and PT Buana Lintas Lautan Tbk through the Indonesia Stock Exchange in the form of an annual company report for three years from 2015-2017. The annual report includes the Board of Commissioners' report, the President Director's report, and the company's financial statements which are intended for shareholders and parties who have an interest in the report.

In the Zmijewski method, there are three indicators of financial ratios combined in a formula, namely earnings after tax to total 
assets (Return on Assets), total debt to total assets (Debt Ratio or Leverage), and current assets to current liabilities (Current ratio or liquidity).

Earning After Tax To Total Assets (X1)

ROA is a ratio that compares net income with total assets. This ratio is used to measure how much a company can utilize its assets in making a profit. The greater the ROA, the more efficient the use of company assets, and vice versa, the smaller the ROA, the more inefficient use of company assets (Sudana, 2011).

Table 3. X1 ROA Calculation Results

\begin{tabular}{lccc}
\hline Company & \multicolumn{3}{c}{ Years } \\
\cline { 2 - 4 } & $\mathbf{2 0 1 6}$ & $\mathbf{2 0 1 7}$ & $\mathbf{2 0 1 8}$ \\
\hline ELTY & -0.0386 & -0.0189 & 0.2004 \\
\hline DKFT & -0.0465 & -0.0197 & -0.0352 \\
\hline BULL & 0.0020 & 0.0360 & 0.0450 \\
\hline
\end{tabular}

Sourcer: Data processed, 2020

Based on the results of calculations X1 at PT Bakrieland Development Tbk during the 2016-2017 period, the company has not been able to utilize the assets owned optimally in generating profits because the results of calculations show growth or loss minus but can then be corrected to profit in 2018, then from the X1 calculation at PT Central Omega Resources Tbk for the period of 2016-2018, the company has not been able to use its assets optimally where during that period continued to suffer losses. For PT Buana Lintas Laut Tbk for the period of 2016-2018, the company's performance showed an increase by generating profits which tended to increase even though it was not optimal, still below $5 \%$ when compared to the assets owned.

Total Debt To Total Assets (X2)

Debt ratio or leverage is a ratio that compares the total debt with total assets. This ratio is used to measure overall company liquidity. The greater this ratio, the greater the use of debt to finance investment in assets, which means the company's financial risk is also increasing.

Table 4. X2 Debt Ration Calculation Results

\begin{tabular}{l|c|c|c}
\hline \multirow{2}{*}{\multicolumn{1}{c}{ Company }} & \multicolumn{3}{|c}{ Years } \\
\cline { 2 - 4 } & $\mathbf{2 0 1 6}$ & $\mathbf{2 0 1 7}$ & $\mathbf{2 0 1 8}$ \\
\hline ELTY & 0.5486 & 0.5623 & 0.2901 \\
\hline DKFT & 0.3529 & 0.4843 & 0.5946 \\
\hline BULL & 0.5869 & 0.4920 & 0.4126 \\
\hline
\end{tabular}

Source: Data processed, 2020

X2 calculation results at PT Bakrieland Development Tbk for the period of 2016-2017, the company is in a bad financial condition because the debt ratio compared to total assets reaches more than $50 \%$, but then shows an improvement in 2018 to $29 \%$. Then the X2 calculation results at PT Central Omega Resources Tbk for the period of 2016-2018, the company's financial position was in a bad condition because the results of total liabilities divided by total assets showed an increase. And the results of $X 2$ calculations at PT Buana Lintas Lautan Tbk in the 2016-2018 period, the company's financial position showed an improvement, with the ratio of total debt compared to total assets tending to decline, although it was still quite high above $40 \%$.

\section{Current Assets To Current Liabilities (X3)}

The current ratio or liquidity is a ratio that compares current assets with current liabilities. This ratio is used to measure the level of company liquidity. A company's liquidity can already be considered good if its current ratio value is equal to 2 . The higher the calculation result of this ratio, the more secure the company's debts to creditors, because for creditors the higher the value of this ratio the better. 
Edon Ramdani: Financial Distress Analysis ...

Table 5. X3 Current Ration Calculation Results

\begin{tabular}{l|c|c|c}
\hline \multirow{2}{*}{ Company } & \multicolumn{3}{|c}{ Year } \\
\cline { 2 - 4 } & $\mathbf{2 0 1 6}$ & $\mathbf{2 0 1 7}$ & $\mathbf{2 0 1 8}$ \\
\hline ELTY & 1.0511 & 0.9836 & 1.9953 \\
\hline DKFT & 1.6296 & 0.8004 & 0.8162 \\
\hline BULL & 1.1041 & 1.0045 & 1.3243 \\
\hline
\end{tabular}

Source: Data processed, 2020
The results of $X 3$ calculations in the three companies show the level of liquidity of the company is in a bad condition because the liquidity of the company will be considered good if the results of the $X 3$ calculation is 2 .

The results of calculations of financial distress with the Zmijewski method.

Table 6. Results of Financial Distress calculations

\begin{tabular}{lllllll}
\hline Years & & $\mathbf{4 . 5}(\mathbf{X 1 )}$ & $\begin{array}{c}\mathbf{5 . 7} \\
(\mathbf{X})\end{array}$ & $\begin{array}{c}\mathbf{0 . 0 0 4} \\
\mathbf{( X 3 )}\end{array}$ & X-Score & Result \\
\hline ELTY & & & & & & \\
\hline 2016 & -4.3 & -0.174 & 3.127 & 0.004 & -1.004 & No Distress \\
\hline 2017 & -4.3 & -0.085 & 3.205 & 0.004 & -1.014 & No Distress \\
\hline 2018 & -4.3 & 0.902 & 1.653 & 0.008 & -3.557 & No Distress \\
\hline DKFT & & & & & & \\
\hline 2016 & -4.3 & -0.209 & 2.012 & 0.007 & -2.086 & No Distress \\
\hline 2017 & -4.3 & -0.089 & 2.760 & 0.003 & -1.454 & No Distress \\
\hline 2018 & -4.3 & -0.159 & 3.390 & 0.003 & -0.755 & No Distress \\
\hline BULL & & & & & & \\
\hline 2016 & -4.3 & 0.009 & 3.345 & 0.004 & -0.968 & No Distress \\
\hline 2017 & -4.3 & 0.162 & 2.805 & 0.004 & -1.662 & No Distress \\
\hline 2018 & -4.3 & 0.203 & 2.352 & 0.005 & -2.156 & No Distress \\
\hline
\end{tabular}

The results of calculations using the Zmijewski method show that the three companies did not experience financial distress because of the negative $X$-Score results in the non-distress category if the X-Score is negative, however, there are some notes given as follows: PT Bakrieland Development Tbk and PT Buana Lintas Lautan Tbk experienced a decrease in the level of financial difficulties, this can be concluded that the two companies have begun to be able to improve their performance by utilizing all the potential assets owned by PT Bakrieland Development Tbk managed to reduce its distress to -3.5565 in 2018 from -1,0035 in 2016 as well as PT Buana Lintas Lautan Tbk managed to reduce its distress level from -0.9682 in 2016 to -2.1561 in 2018. PT Central Omega Resources Tbk, from the above calculation results, show that the company has not been able to optimize its potential in terms of managing its assets and can be seen that the level of distress has increased from -2.0858 in 2016 to -0.7553.

\section{CONCLUSION}

Financial distress in a company can occur due to various factors in terms of economy, finance, governance (lack of experience of superiors or subordinates) in running a business, inappropriate capabilities, and also limited skills and other factors. Financial difficulties must be anticipated so that companies avoid bankruptcy. Financial difficulties can be analyzed from the company's performance through its financial statements by using financial ratios and also various analytical models such as Springate, Grover, Zmijewski Method, and also another modeling. Every company listed on the Indonesia Stock Exchange should report its financial position regularly. Through these financial statements, the stock exchange and investors can see the company's performance. Companies that do 
not timely report their financial statements can be a negative signal for investors.

This research focuses on companies that can be reprimanded from the IDX due to delays in their financial statements and based on the results of an analysis of the possibility of financial distress in the three companies, PT Bakrieland Development Tbk, PT Central Omega Resources Tbk, and PT Buana Lintas Lautan Tbk by analyzing financial statements during the 2016 period Until 2018, which uses the Zmijewski method, the three companies are in the category of healthy or non-distress, this is based on X-Score measurements where significant negative value is obtained in a healthy condition. However, based on the financial statements of PT Bakrieland Development TBK experienced a negative profit in 2016 and 2017 as well as PT Central Omega Resources Tbk which experienced a minus profit throughout 2016 to 2018 for that the company is required to be able to maintain its performance and continue to be able to meet its obligations and slowly reduce the level of liability so that it can be maintained does not lead to financial difficulties. For this reason, the company will continue to increase sales results to the extent that it is expected that its net profit can be maintained and greater than its liabilities. This research uses the Zmijewski method which is easy to apply but the results can be different if using other methods such as Grover, Fulmer, and others.

\section{REFERENCES}

Altman, Edward I and Hotchkiss, Ed. (2006). Corporate Financial Distress and Bankruptcy. 3th Edition. USA: John Wiley \& Sons, Inc.

Beaver, W. H. et al. (2011). Financial Statement Analysis and the Prediction of Financial Distress. Foundations and Trends in Accounting, 5(2), 99-173.

Kusumaningtyas, D. (2017). Bankruptcy Prediction Analysis Using Zmijewski, Springate, and Fulmer Models at Retail
Companies on the Indonesia Stock Exchange. Skripsi. STIE Perbanas Surabaya.

Dun and Breadstreet, Inc. (2011). E-book The Business Failure Record. California: Business Economics Division, Dun and Breadstreet.

Elloumi, F., and Gueyie, J. P. (2001). Financial Distress and Corporate Governance: An Empirical Analysis. Corporate Governance: The international journal of business in society, 1 (1), 15-23.

Endang A. (2013). Financial Ratios. Financial Distress Company. Review of the Arthavidya Journal, 14(1), 41-51.

Hsin, H. C. (2008). The Timescale Effects of Corporate Governance Measure on Predicting Financial Distress. Review of Pacific Basin Financial Markets and Policies, 11(1), 35-46.

Liou, D. K., and M. Smith. (2007). Macroeconomic Variables and Financial Distress. Journal of Accounting - Business \& Management, 14, 17-31.

Lizal, L. (2002). Determinants of financial distress: What drives bankruptcy in a transition economy? The Czech republic case. William Davidson Working Paper, 451.

Permana, R.K. et al. (2017), Prediction of Financial Distress in Manufacturing Companies on the Indonesia Stock Exchange. Journal of Business and Management, 7(2).

Permatasari, D. et al. (2019). Financial Distress Analysis with The Zmijewski Method. Journal of Business and Management, 1(1).

Purnajaya, K. D. M., and Merkusiwati, N. K. L. A. (2014). Comparative Analysis of Potential Bankruptcy with the Altman, Springate, and Zmijewski Z-Score Method in the Cosmetics Industry Listed on the Indonesia Stock Exchange. EJournal of Accounting, 7(1), 48-63. 
Peter, Y. (2011). Bankruptcy Analysis Using the Altman, Springate, and Zmijewski ZScore Method in PT Indofood Sukses Makmur Tbk Period 2005-2009. Accurate Accounting Scientific Journal, 04(2).

Ray, S. (2011). Assessing Corporate Financial Distress in Automobile Industry of India: An Application of Altman's Model, Research Journal of Finance and Accounting, 2(3), 155-169.

Rismawaty (2012). Comparative Analysis of the Financial Distress Prediction Model Altman, Springate, Ohlson, and Zmijewski (Empirical Study of Food and Beverages Companies Listed on the
Indonesia Stock Exchange). Thesis. Hasanuddin University.

Rodoni, A and Ali, H. (2010). Financial management. Jakarta: Mitra.

Sudana, I., M. (2011). Corporate Financial Management Theory \& Practice, First Matter. Jakarta: Erlangga.

S, Patricia Febriml D. (2010). Causes, Impacts and Predictions of Financial Distress and Solutions to Overcome Financial Distress. Contemporary Accounting Journal, 2(2).

Sugiyono 2018. Quantitative, Qualitative, and $R \& D$ Research Methods. Bandung: Alfabeta

www.idx.co.id 